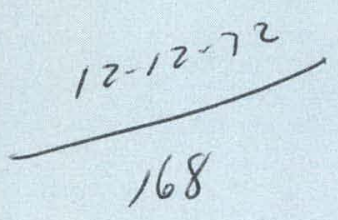

\title{
IMPROVING THE Y-12 NEUTRON RADIOGRAPHY FACILITY
}

E. M. Murray

J. L. Telford 


\section{DISCLAIMER}

This report was prepared as an account of work sponsored by an agency of the United States Government. Neither the United States Government nor any agency Thereof, nor any of their employees, makes any warranty, express or implied, or assumes any legal liability or responsibility for the accuracy, completeness, or usefulness of any information, apparatus, product, or process disclosed, or represents that its use would not infringe privately owned rights. Reference herein to any specific commercial product, process, or service by trade name, trademark, manufacturer, or otherwise does not necessarily constitute or imply its endorsement, recommendation, or favoring by the United States Government or any agency thereof. The views and opinions of authors expressed herein do not necessarily state or reflect those of the United States Government or any agency thereof. 


\section{DISCLAIMER}

Portions of this document may be illegible in electronic image products. Images are produced from the best available original document. 


\section{Printed in the United States of America. Available from National Technical Information Service \\ U.S. Department of Commerce \\ 5285 Port Royal Road, Springfield, Virginia 22151}

Price: Printed Copy $\$ 3.00$; Microfiche $\$ 0.95$

This report was prepared as an account of work sponsored by the United States Government. Neither the United States nor the United States Atomic Energy Commission, nor any of their employees, nor any of their contractors, subcontractors, or their employees, makes any warranty, express or implied, or assumes any legal liability or responsibility for the accuracy, completeness or usefulness of any information, apparatus, product or process disclosed, or represents that its use would not infringe privately owned rights.

Reference to a company or product name does not imply approval or recommendation of the product by Union Carbide Corporation or the U S Atomic Energy Commission to the exclusion of others that may meet specifications. 


\title{
IMPROVING THE Y-12 NEUTRON RADIOGRAPHY FACILITY
}

\author{
E. M. Murray
}

J. L. Telford

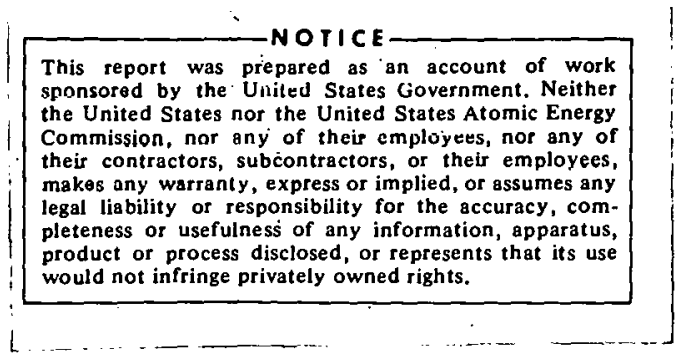

\section{Oak Ridge Y-12 Plant}

P.O. Box Y, Oak Ridge, Tennessee 37830

operated for the U.S. ATOMIC ENERGY COMMISSION bY UNION CARBIDE CORPORATION-NUCLEAR DIVISION under Contract W-7405-eng-26

Date Issued - November 18, 1972 


\begin{abstract}
To improve the Y-12 Neutron Radiography Facility, a series of four experiments were conducted. The factors which appeared to be most important for this facility have been identified and the best operating conditions determined. The overall improvement made was quite significant.
\end{abstract}


CONTENTS

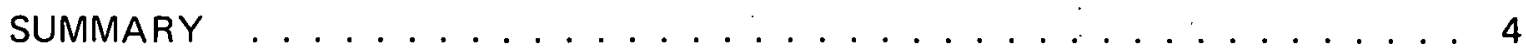

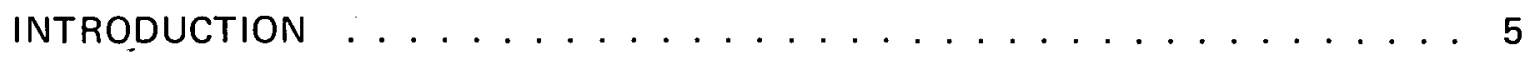

RADIOGRAPHY FACILITY EVALUATION ............. 9

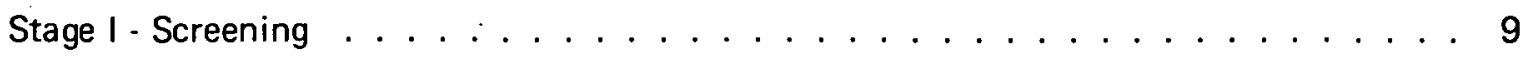

Stage 11 - Preliminary Tuning . . . . . . . . . . . . . . 11

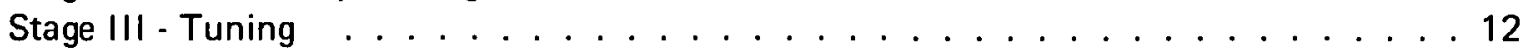

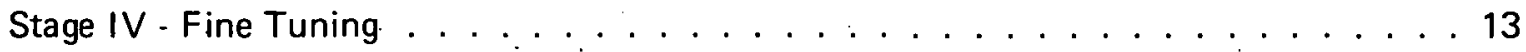

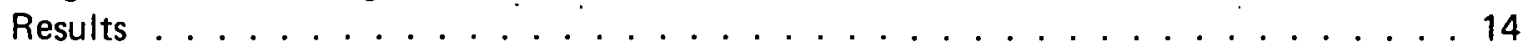

CONCLUSIONS AND RECOMMENDATIONS $\ldots \ldots \ldots \ldots \ldots$

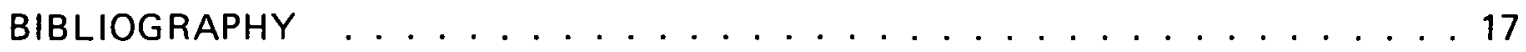


An experimental program has been conducted to determine the best operating conditions for the Y-12 Neutron Radiography Facility. The program was divided into four experiments: Stage I consisted of an evaluation of the effects of five factors: (1) collimator ratio, (2) beam extraction geometry (the distance in inches the source is moved off the axis of the collimator), (3) bismuth shield (inches), (4) air gap (inches), and (5) moderator (inches). Stage II was concerned with a further evaluation of the same five factors but in a new region which was pointed out by Stage I. Stage III involved an evaluation of the effects of the first three factors: collimator ratio, beam extraction geometry, and bismuth shield. Stage IV was designed to accomplish a fine tuning of the levels of beam extraction geometry and bismuth shield.

Three criteria were observed: (1) $\mathrm{Cf} / \mathrm{f}$ ratio (density of film with cadmium divided by density of film without cadmium), (2) CRASI (contrast, resolution, and scatter indicator) index, a measure of neutron scatter, and (3) VISQI (visual image, scatter, and quality indicator) faults, a judgement of radiographic resolution.

The important factors for this facility have been identified. The best operating conditions produced significant improvements. It is recommended that a more flexible facility (in terms of radiographic parameters) be established and optimized. 


\section{INTRODUCTION}

A neutron radiography facility was installed and operating in the Oak Ridge Y-12 Plant (a) by November 1971. Figure 1 provides a view of the complete facility. Neutrons are emitted by a 10-milligram source of californium-252. Thermal neutrons are, in turn, produced in a one-foot cube of high-density polyethylene surrounding the neutron source, seen to the left of center in Figure 2. A gadolinium vacuum-deposited screen was used in conjunction with Kodak AA film in a vacuum cassette. The screen and cassette are shown in Figure 3. All collimators used are internally coated with boron. The collimators can be seen in Figure 4 .

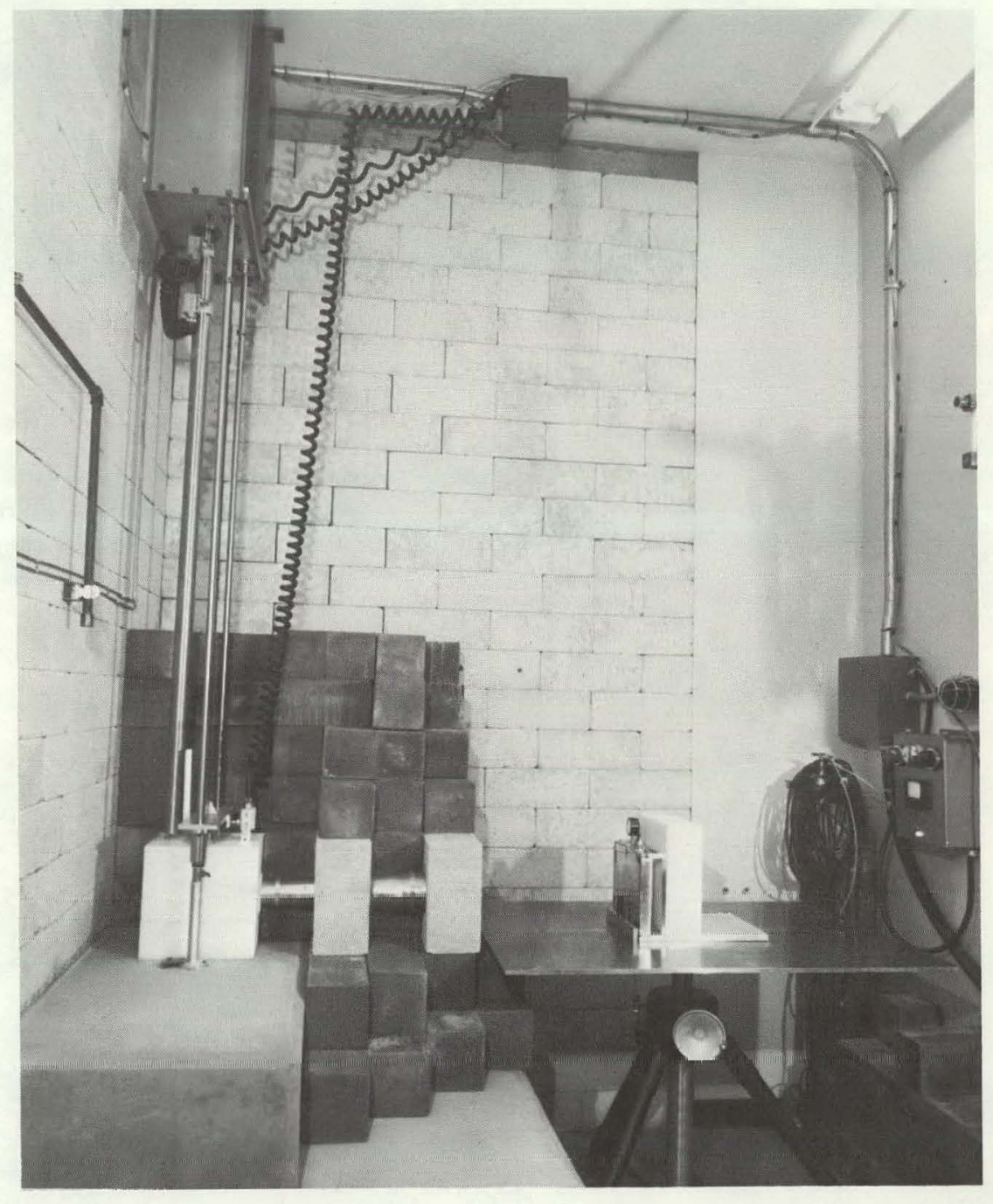

142793

Figure 1. NEUTRON RADIOGRAPHY FACILITY.

(a) Operated for the US Atomic Energy Commission by the Union Carbide Corporation's Nuclear Division. 


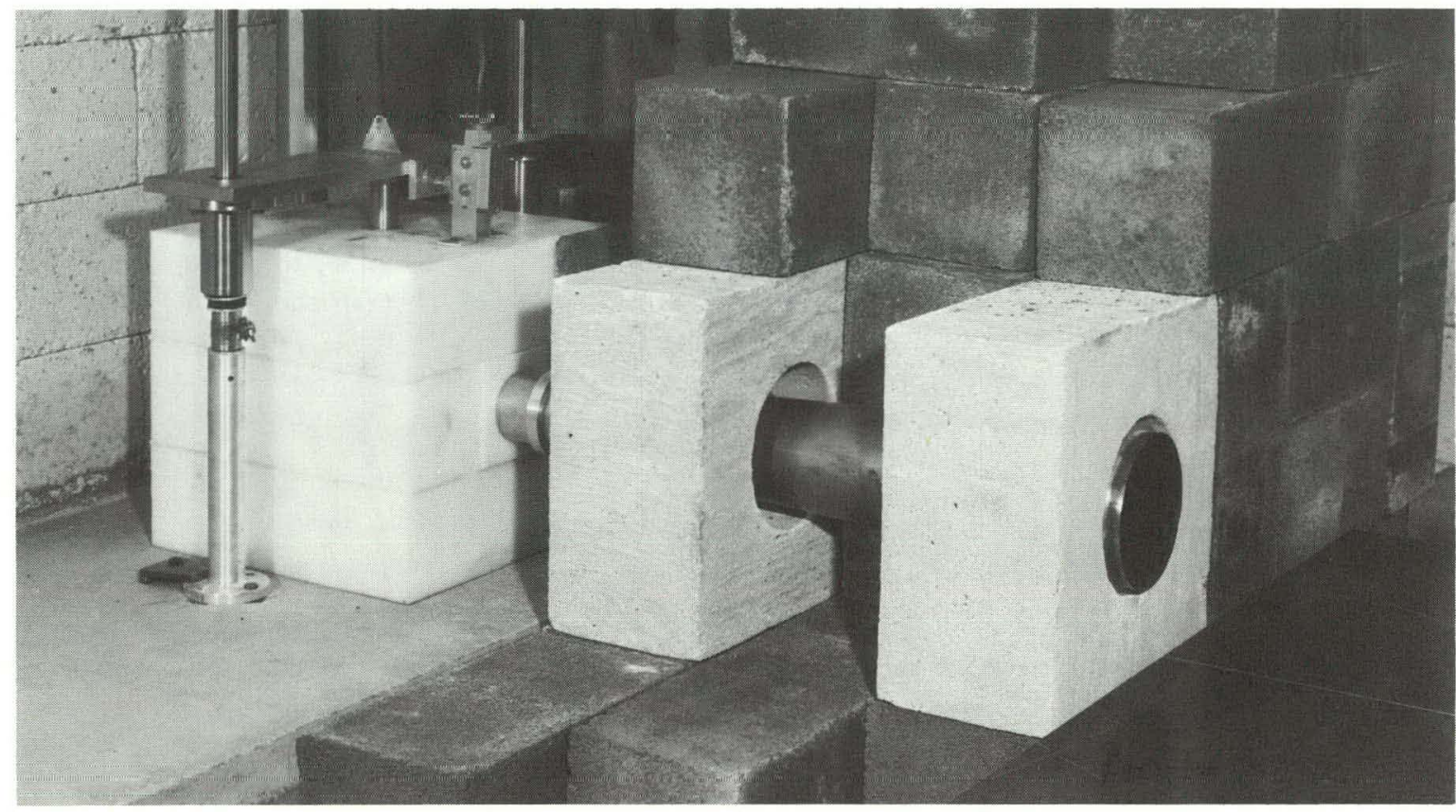

142795

Figure 2. POLYETHYLENE CUBE CONTAINING THE NEUTRON SOURCE.

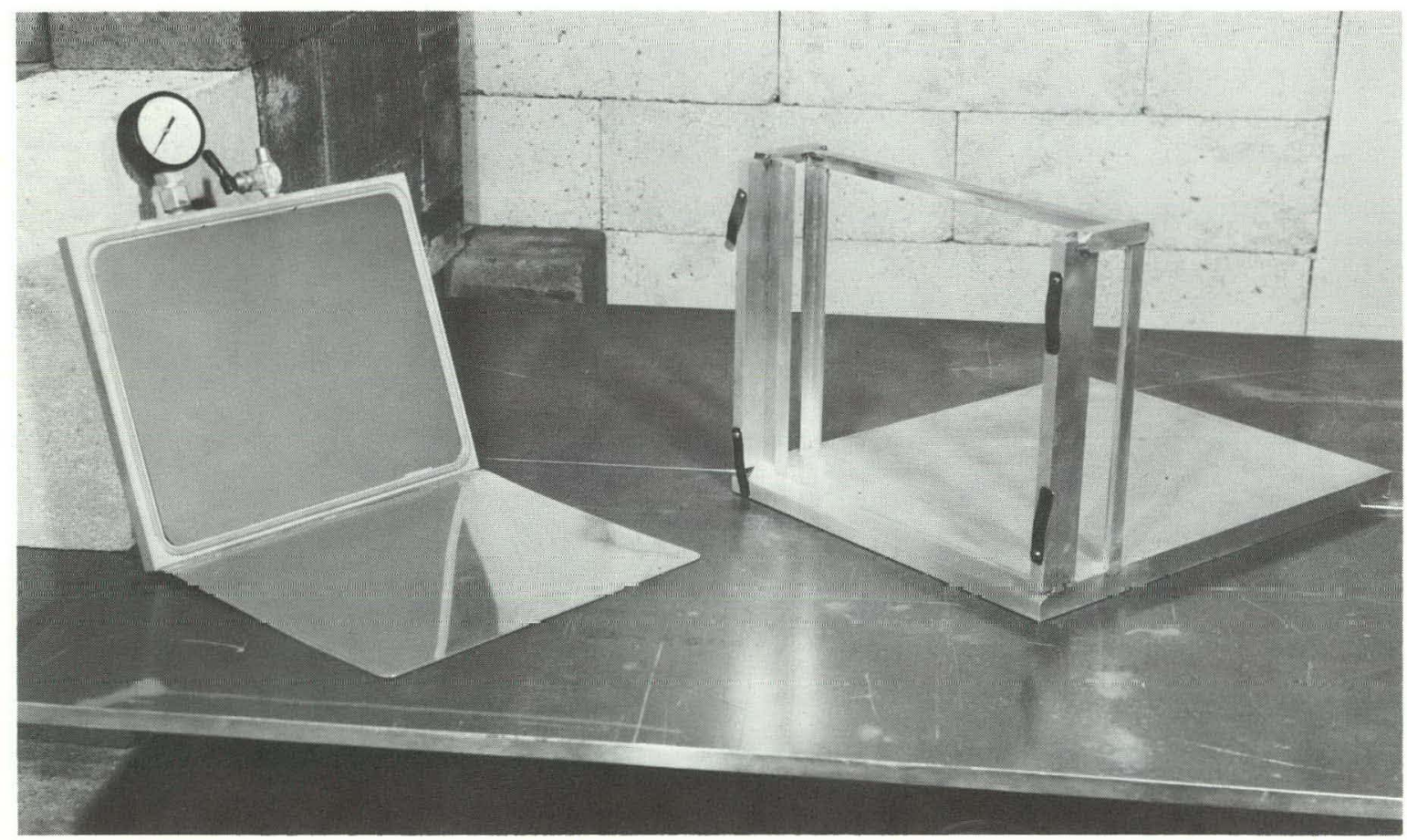

142801

Figure 3. GADOLINIUM SCREEN AND CASSETTE. 


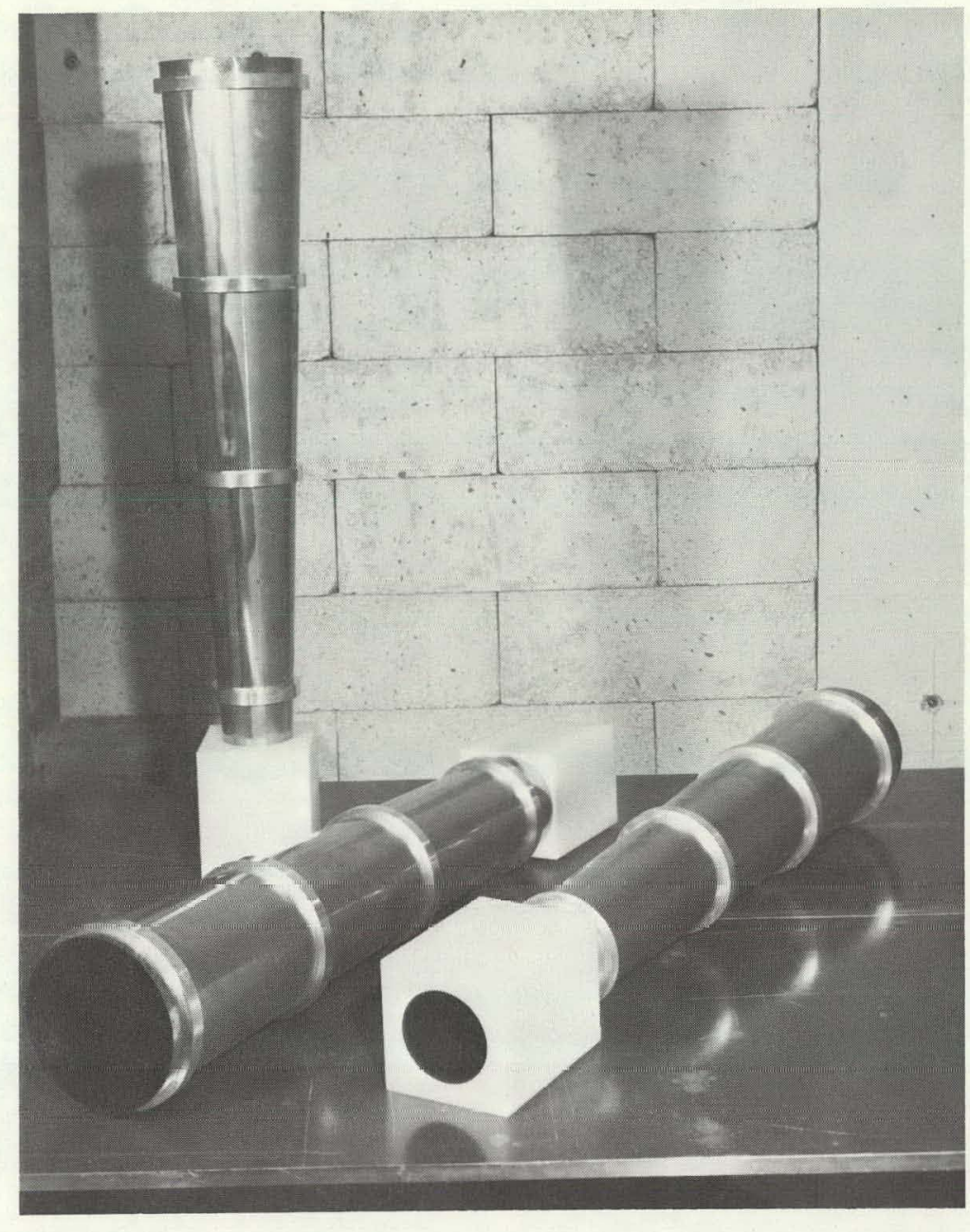

Figure 4. SOURCE COLLIMATORS.

142799

This experimental program was designed to determine the best operating conditions. The program was divided into four experiments (stages). In order to obtain the most information per unit of time spent, Stages I and II were statistical designs known as fractional factorials; Stages III and IV were full factorials.

Five factors were of interest. The factors and their restrictions were:

1. Collimator Ratio - threc collimators with fixed ratios.

2. Beam Extraction Geometry (source position) - highly adjustable in one direction.

3. Air Gap - a physical range from zero to three inches.

4. Moderator Shield (bismuth) - a physical range from zero to three inches.

5. Moderator Gap - a physical range from zero to three inches. 
It was desired to observe three criteria: (1) $\mathrm{Cf} / \mathrm{f}$ ratio (the density of film with cadmium divided by density of film without cadmium; (2) CRASI (contrast, resolution, and scatter indicator), and (3) VISQI (visual image, scatter, and quality indicator), a judgement of radiographic resolution. 


\section{RADIOGRAPHY FACILITY EVALUATION}

\section{STAGE I - SCREENING}

The factors investigated in the first step were adjustable and thought to have some effect on the observed response.

The two levels of each factor that were explored in the first stage are listed in Table 1.

The factors, or interaction of factors, which had a significant effect on $\mathrm{Cf} / \mathrm{f}$ were: (1) interaction of the collimator ratio with the air gap, and (2) interaction of the source position with the moderator. These interactions of factors are illustrated in Figure 5.

To interpret the graph of Figure 5, picture a hillside across each graph (perpendicular to the plane of the graph). The average $\mathrm{Cf} / \mathrm{f}$ value is the altitude at that point on the hillside. $A$ minimum value for $\mathrm{Cf} / \mathrm{f}$ is desired. The arrows are pointing in the probable direction of the minimum value. This new region was investigated in Stage 11.
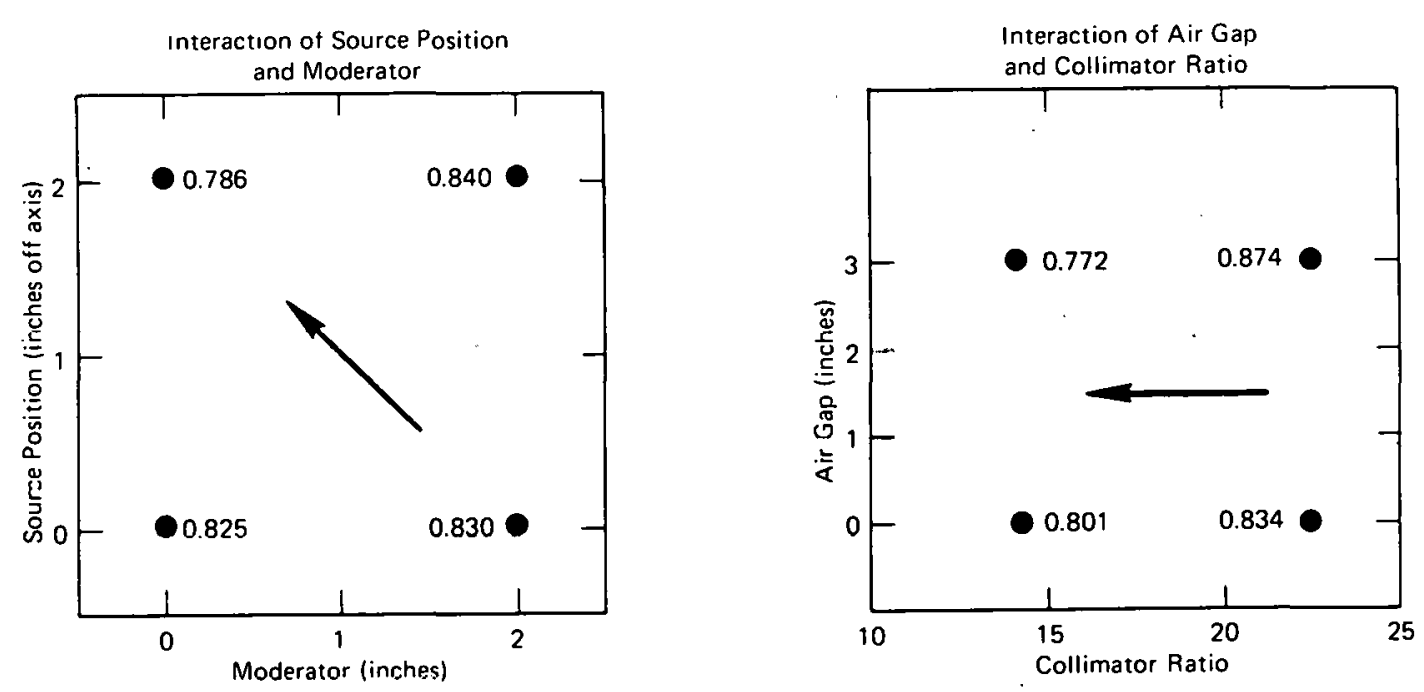

Figure 5. Cf/f - IMPORTANT FACTORS.

The factors or interaction of factors which had a significant effect on CRASI were: (1) the moderator, (2) interaction of the collimator ratio with the air gap, and (3) interaction of the source position with the bismuth shield.

It was desired to find a maximum value for CRASI. The effect of the moderator was that a larger moderator decreased the CRASI. In Stage 11, much smaller thicknesses for the 
moderator were investigated. The interactions of factors are illustrated in the graph of Figure 6. The average CRASI value is the altitude at that point on the hillside. The arrows are pointing in the probable direction of the maximum value. This new region was investigated in Stage 11.
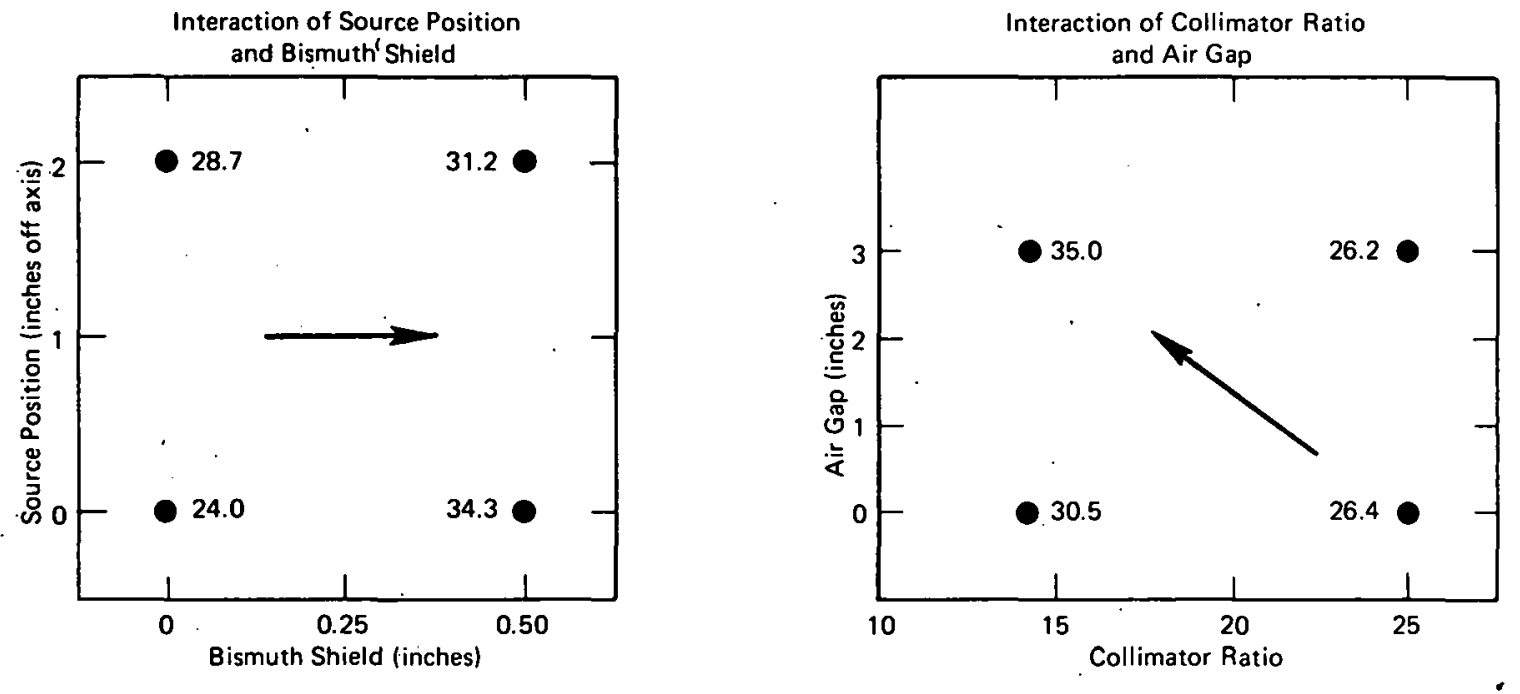

Figure 6. CRASI INDEX - IMPORTANT FACTORS. (Stage I)

The factors and interactions of factors which had a significant effect on the VISQI were: (1) source position, (2) moderator, (3) interaction of the collimator ratio with the bismuth shield, and (4) interaction of the collimator ratio with the air gap. A minimum value for VISQI was desired. The effect of the source position was to increase VISQI faults as the source position was moved off the axis. The effect of the moderator was an increase of VISQI faults for an increase of the moderator. The interactions of factors are illustrated in Figure 7. As before, the average VISOI value is the altitude at that point on the hillside.
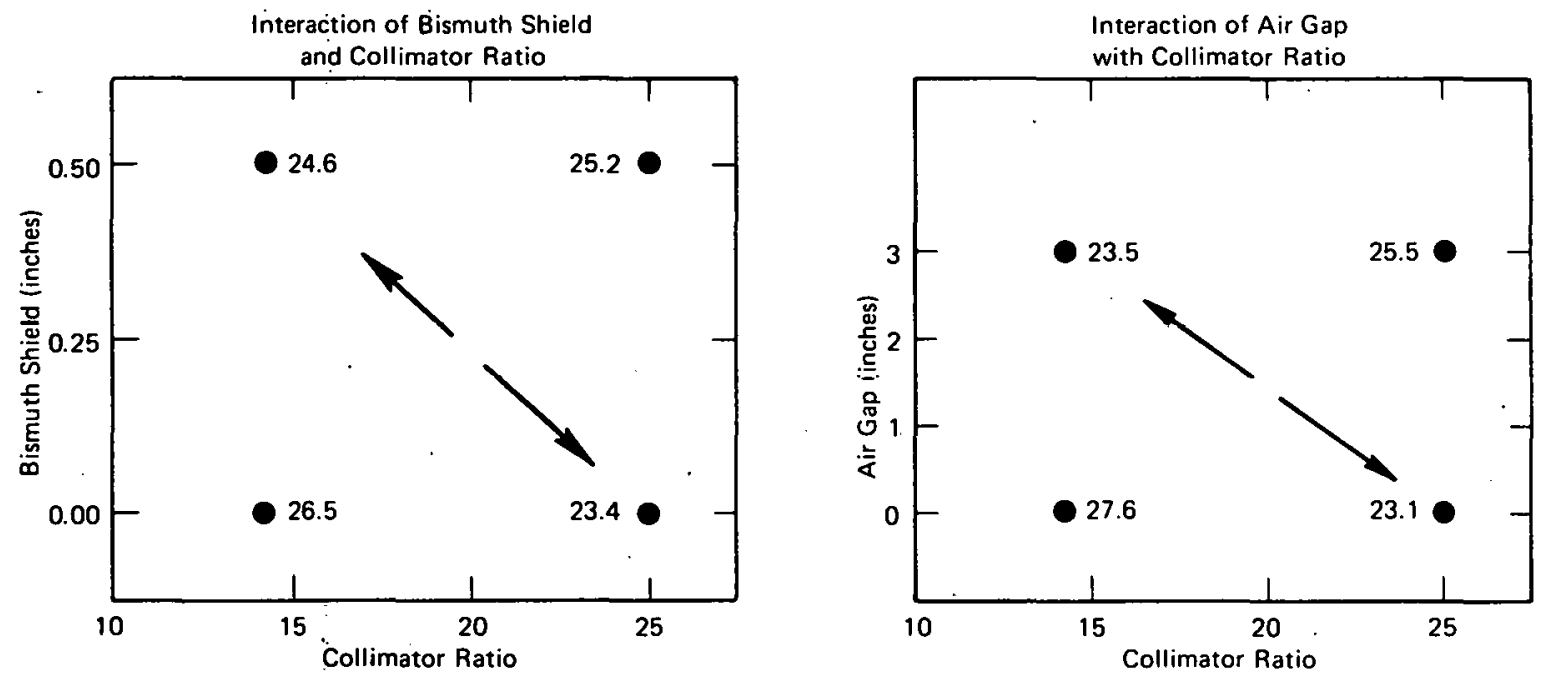

Figure 7. VISQI FAULTS - IMPORTANT FACTORS. (Stage I) 
The arrows are pointing to a valley which is the desired location. If the collimator ratio is decreased, the air gap should be increased; and, likewise, the amount of bismuth shield should be increased. Since VISQI is an opinion (not a measurement) it was not valued as much as either Cf/f or CRASI. In Stage II, new levels for all factors were chosen, principally to improve $\mathrm{Cf} / \mathrm{f}$ and CRASI.

\section{STAGE II - PRELIMINARY TUNING}

Table 2

The two levels of each factor that were explored in Stage $1 \mathrm{I}$ are given in Table 2.

The factors which had a significant effect on $\mathrm{Cf} / \mathrm{f}$ were: (1) source position, (2) collimator ratio, and (3) bismuth shield. The average $\mathrm{Cf} / \mathrm{f}$ values for each important factor at high and low levels are listed in

FACTORS EXPLORED IN STAGE II

\begin{tabular}{lcr}
\hline & \multicolumn{2}{c}{ Levels } \\
\cline { 3 - 3 } \multicolumn{1}{c}{ Factors } & Low & High \\
\hline Collimator Ratio & 14.3 & 18.2 \\
Source Position (inches off axis) & 0.5 & 1.5 \\
Bismuth Shield (inches) & 0.5 & 1.0 \\
Air Gap (inches) & 1.5 & 3.0 \\
Moderator (inches) & 0 & 0.5 \\
\hline
\end{tabular}
Table 3.

This information implies that to improve $\mathrm{Cf} / \mathrm{f}$ for Stage III, changes should be made that would: move the source position further off the axis, decrease the collimator ratio, and add more bismuth shield.

The interactions of factors which had a significant effect on CRASI were: (1) interaction of the source position with the bismuth shield, and (2) interaction of the air gap with the moderator.
Table 3

IMPORTANT FACTORS - $\mathrm{CF} / \mathrm{f}$ STAGE II

(Average $\mathrm{Cf} / \mathrm{f}$ Values - Minimize)

\begin{tabular}{lll}
\hline \multirow{2}{*}{ Factors } & \multicolumn{2}{c}{ Levels } \\
\cline { 2 - 3 } & Low & High \\
\hline Source Position & 0.747 & 0.709 \\
Collimator Ratio & 0.721 & 0.736 \\
Bismuth Shield & 0.741 & 0.716 \\
\hline
\end{tabular}

The interactions of factors are illustrated in the graph of Figure 8 . Figure 8 should be interpreted as before. The average CRASI value is the altitude at that point on the hillside. The arrows are pointing in the probable direction of the maximum value. In Stage III, a new region for the factors source position and bismuth shield were investigated; a moderator was omitted.

The factor and interactions of factors which had a significant effect on VISQI were: (1) collimator ratio, (2) interaction of the air gap with the bismuth shield, and (3) interaction of the source position with the moderator. The effect of the collimator ratio was to decrease VISQI faults as the collimator ratio was increased, which was opposite to the result for $\mathrm{Cf} / \mathrm{f}$. The two interactions of factors are illustrated in Figure 9 . Figure 9 should be interpreted as before. For the interaction of the air gap with the bismuth shield, the arrow is pointing in the probable direction of the minimum value; for the interaction of the source position with the moderator, the arrows are pointing out a valley which is the desired location. In Stage III, the levels for the collimator ratio, source position, and bismuth shield factors were chosen principally to improve the Cf/f and CRASI. 

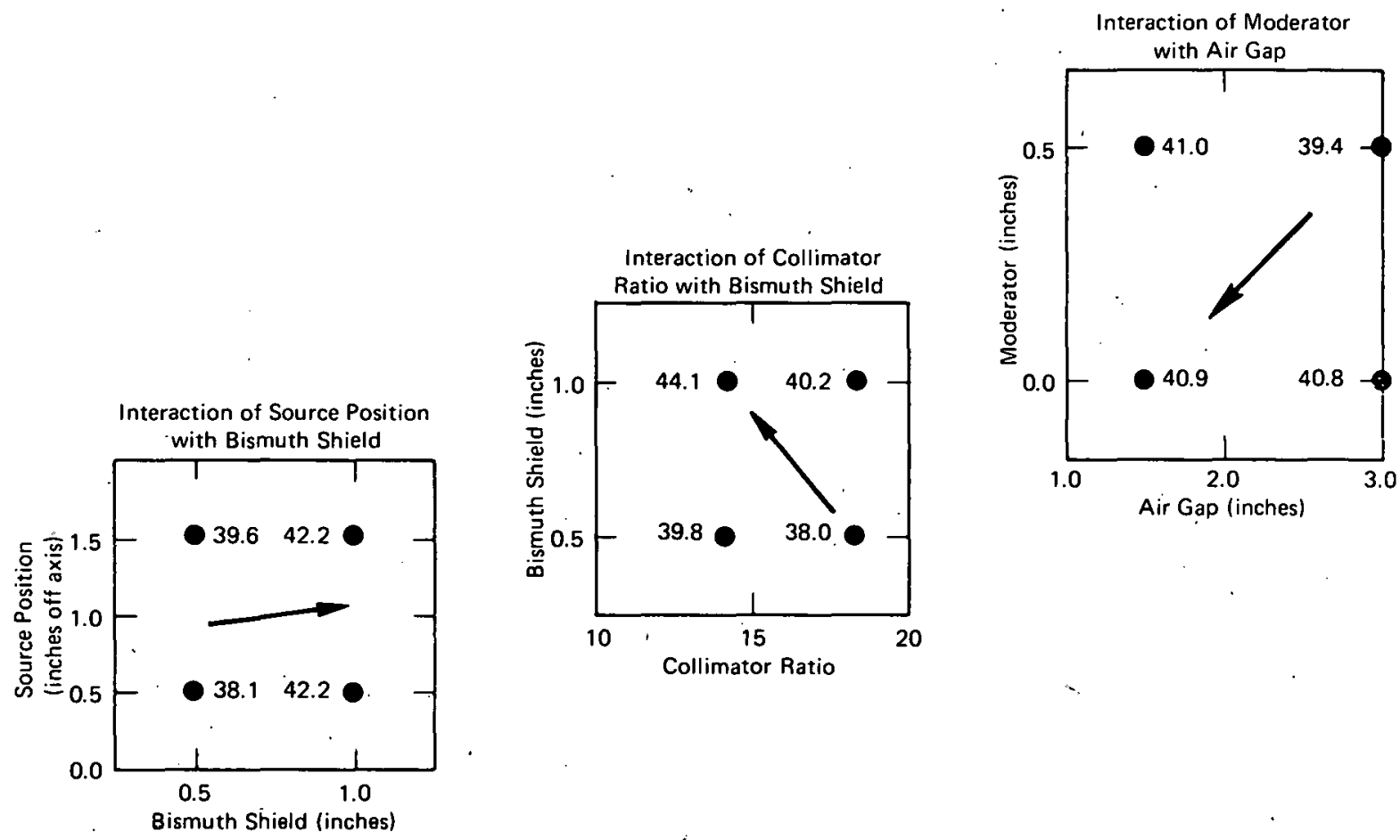

Figure 8. CRASI INDEX - IMPORTANT FACTORS. (Stage II)
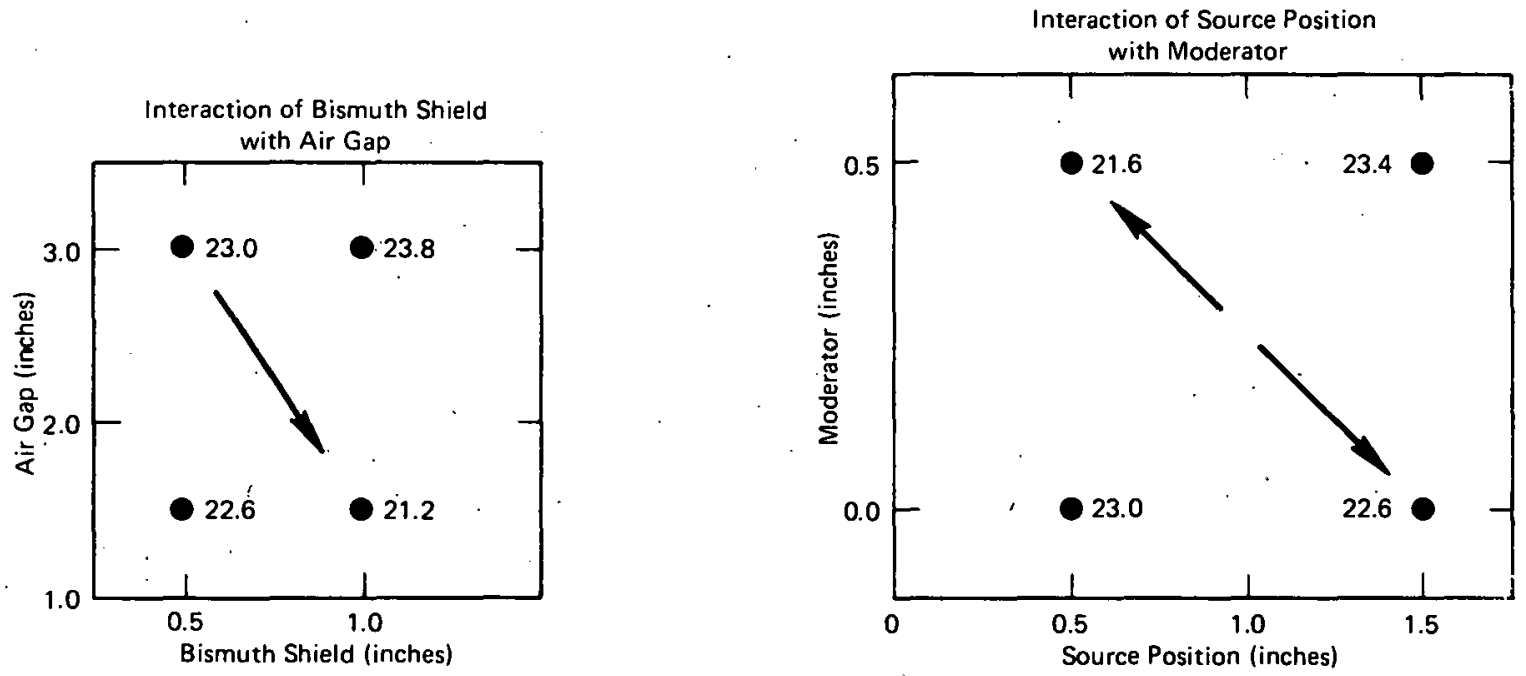

Figure 9. VISQ̣ı FAULTS - IMPORTANT FACTORS. (Stage II)

\section{STAGE III - TUNING}

The two levels of each factor that were explored in Stage 111 are given in Table 4.

The moderator was omitted and the air gap was set at one and one-half inches.
Table 4

FACTORS EXPLORED IN STAGE III

\begin{tabular}{lcc}
\hline & \multicolumn{2}{c}{ Levels } \\
\cline { 2 - 3 } Factors & Low & High \\
\hline Collimator Ratio & 14.3 & 18.2 \\
Source Position (inches off the axis) & 1.0 & 2.0 \\
Bismuth Shield (inches) & 1.25 & 1.50 \\
\hline
\end{tabular}


The factors which had a significant effect on $\mathrm{Cf} / \mathrm{f}$ were: (1) source position, (2) collimator ratio, and (3) bismuth shield. The average $\mathrm{Cf} / \mathrm{f}$ value for each factor at high and low levels is listed in Table 5.

To improve $\mathrm{Cf} / \mathrm{f}$, the bismuth shield should be increased and the source positions of one and one and one-half inches explored (considering Tables 2 and 4).

The interaction of factors which had a significant effect on CRASI was the interaction of the source position with the collimator ratio. The average CRASI values for each combination of these two factors are summarized in Table 6.

The factor which had a significant effect on VISQI was the source position. The effect of the source position was to increase VISQI as the source was moved away from the axis.
Table 5

IMPORTANT FACTORS - Cf/f STAGE III

(Average $\mathrm{Cf} / \mathrm{f}$ Values - Minimize)

\begin{tabular}{lll}
\hline \multirow{2}{*}{ Factors } & \multicolumn{2}{c}{ Levels } \\
\cline { 2 - 3 } & Low & High \\
\hline Source Position & 0.699 & 0.731 \\
Collimator Ratio & 0.705 & 0.726 \\
Bismuth Shield & 0.721 & 0.710 \\
\hline
\end{tabular}

Table 6

IMPORTANT FACTORS - CRASI STAGE III

(Average CRASI Values - Maximize)

\begin{tabular}{llr}
\hline $\begin{array}{c}\text { Source } \\
\text { Positions } \\
\text { (inches) }\end{array}$ & \multicolumn{2}{c}{ Collimator Ratios } \\
\cline { 2 - 3 } & 14.3 & 18.2 \\
\hline 1.0 & 48.2 & 44.3 \\
2.0 & 43.0 & 35.0 \\
\hline
\end{tabular}

\section{STAGE IV - FINE TUNING}

In Stage IV, the factors of source position and bismuth shield were explored.

The levels of each factor that were explored in Stage IV are reported in Table 7.

Table 7

FACTORS EXPLORED IN STAGE IV

\begin{tabular}{|c|c|c|c|}
\hline \multirow[b]{2}{*}{ Factors } & & \multicolumn{2}{|c|}{ Levels } \\
\hline & & Low & High \\
\hline \multicolumn{4}{|c|}{ Step 1} \\
\hline Source Position (inches) & & 1.0 & 1.5 \\
\hline Bismuth Shield (inches) & & 1.75 & 2.25 \\
\hline \multicolumn{4}{|c|}{ Step 2} \\
\hline Source Position (inches) & & 1.0 & 1.5 \\
\hline Bismuth Shield (inches) & & 2.25 & 2.75 \\
\hline
\end{tabular}

Table 8

IMPORTANT FACTORS - Cf/f - STAGE IV (Cf/f Values - Minimize)

\begin{tabular}{llcl}
\hline $\begin{array}{l}\text { Source } \\
\begin{array}{l}\text { Position } \\
\text { (inches) }\end{array}\end{array}$ & \multicolumn{3}{c}{ Bismuth Shield (inches) } \\
\cline { 2 - 4 } & 1.75 & 2.25 & 2.75 \\
\hline 1.0 & 0.676 & 0.658 & 0.669 \\
1.5 & 0.659 & 0.672 & 0.679 \\
\hline
\end{tabular}

The moderator was omitted, the air gap was set at one and one-half inches, and the collimator ratio was set at 14.3.

The results of this fine tuning was that for both $\mathrm{Cf} / \mathrm{f}$ and CRASI the best results were obtained with the source position one inch off the axis and with two and one-quarter inches of bismuth shield. The results of Stage IV are recorded in Tables 8 and 9 .

Table 9

IMPORTANT FACTORS - CRASI - STAGE IV (CRASI Values - Maximize)

\begin{tabular}{lccc}
\hline $\begin{array}{l}\text { Source } \\
\text { Position } \\
\text { (inches) }\end{array}$ & \multicolumn{3}{c}{ Bismuth Shield (inches) } \\
\cline { 2 - 4 } & 1.75 & 2.25 & 2.75 \\
\hline 1.0 & 50.0 & 50.4 & 48.8 \\
1.5 & 49.3 & 48.8 & 48.3 \\
\hline
\end{tabular}




\section{Results}

The best overall response (considering $\mathrm{Cf} / \mathrm{f}, \mathrm{CRASI}$, and VISQI) was obtained using Kodak AA film under the following conditions: an air gap of one and one-half inches, a collimator ratio of 14.3 (collimator inlet diameter of 3.5 inches), no moderator gap, source position of one inch off the axis, two and one quarter inches of bismuth shield, and an exposure time of two hours. Figure 10 is a positive print of a neutron radiograph made under the conditions

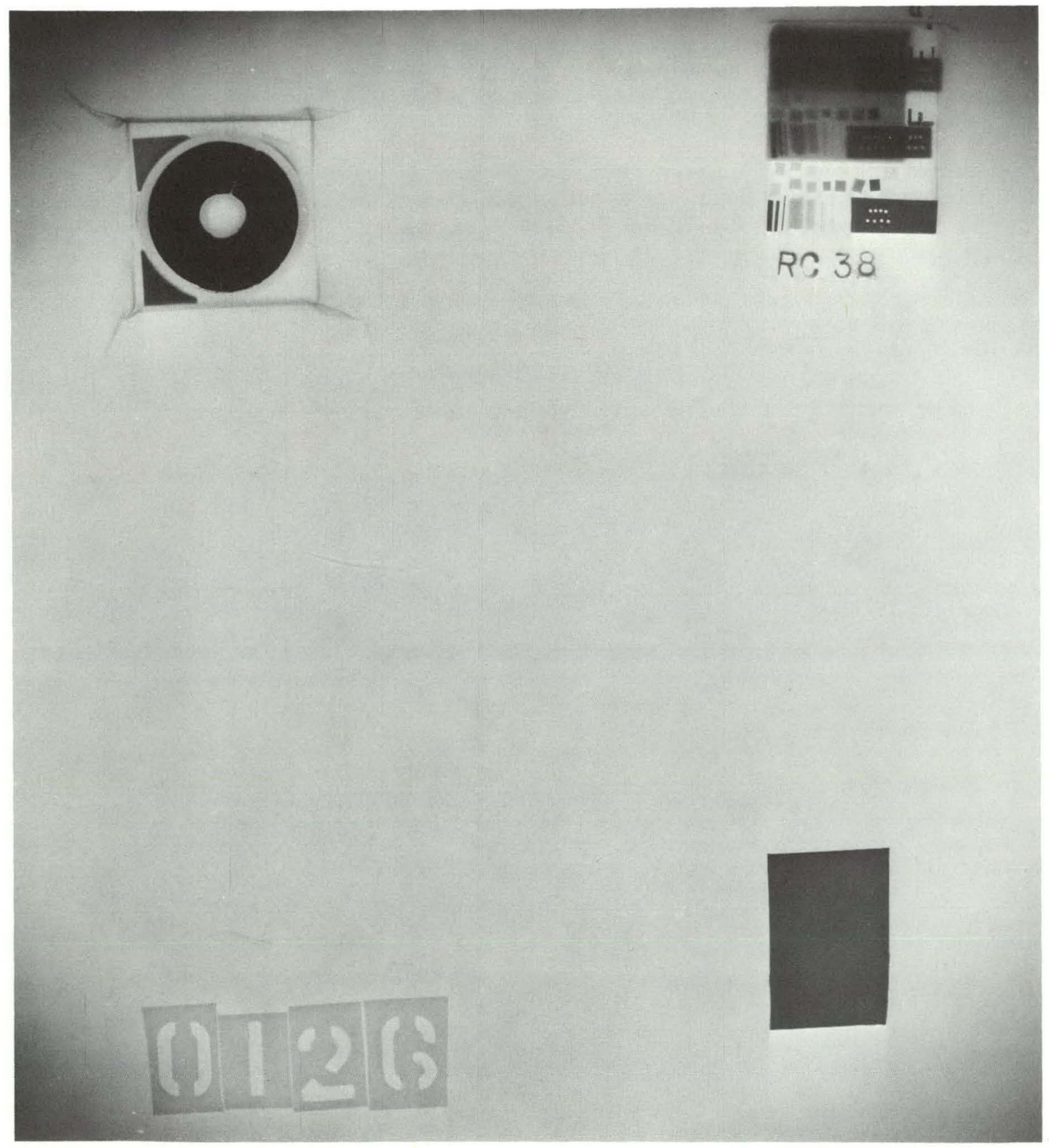

Figure 10. POSITIVE PRINT OF A NEUTRON RADIOGRAPH. 
just listed. It contains a VISQI object, a CRASI object, a 0.020 -inch cadmium plate, and polyethylene numbers for identification. This radiograph had a CRASI index of 50.8 percent and a $\mathrm{Cf} / \mathrm{f}$ ratio of 0.654 .

Overall, the improvement made in this facility was quite significant. The number of VISQI faults was slightly reduced from an average of 24.9 to an average of 23.5. This number of VISQI faults could be reduced further by increasing the collimator ratio, but this would adversely affect the $\mathrm{C} f / \mathrm{f}$ ratio and CRASI index.

The $\mathrm{Cf} / \mathrm{f}$ ratio was reduced from an average of 0.820 to an average of 0.658 , a 19.8 percent improvement. The CRASI index was increased from an average of 29.6 to an average of 50.4, a 70.3 percent improvement. 


\section{CONCLUSIONS AND RECOMMENDATIONS}

The following conclusions can be stated as a result of this study:

1. Significant improvements were made for both the $\mathrm{cf} / \mathrm{f}$ ratio (film contrast) and the CRASI index (neutron scatter).

2. Considered singly, the number of VISOI faults (radiographic resolution) could be improved further.

It is recommended that the various radiographic parameters be made more flexible (ie, a more variable collimator ratio and more air gap space). A variable-ratio collimator system has been manufactured. This variable-ratio collimator system should be optimized. 


\section{BIBLIOGRAPHY}

Cochran, W. G. and Cox, G. M.; Experimental Designs; John Wiley and Sons, Inc, New York, New York (1968).

Ostle, B.; Statistics in Research; lowa State University Press, Ames, lowa (1963). 


\section{DISTRIBUTION}

Atomic Energy Commission-ORO

Hickman, H. D.

Zachry, D. S., Jr

Dow-Rocky Flats

Stump, W. D.

\section{Lawrence Livermore Laboratory}

- Liptai, R. G.

Los Alamos Scientific Laboratory

Elliot, D. E.

Oak Ridge Gaseous Diffusion Plant

Wilcox, W. J., Jr

Winkel, R. A.

Oak Ridge Y-12 Plant

Alvey, $H, F$.

Bailey, H. L.

Bernander, N. K.

Burditt, R. B.

Burkhart, L. E.

Denny, A. (2)

Ellingson, R. D.

Fitzgerald, C. M.

Foulk, D. L.

Garber, J. M.

Gritzner, V. B.

Hemphill, L. F.

Hensley, C. E.

Jackson, V. C.

Jones, F. W.
Kahl, K. G.

Keith, Alvin

Knowles, C. M.

Mason, D. L.

Mitchel. G. W.

Oliphant, G. W.

Perry, A. E.

Reavis, J. P.

Schreyer, J. M.

Smith, H. F., Jr

Smith, J. H.

Smith, R. D.

Snow, S. G.

Stoner, H. H.

Telford, J. L. (12)

Tilson, F. V.

Trotter, T. C.

Weathersby, W. E.

White, J. D.

Yaggi, W. J.

Y-12 Central Files (5)

$Y-12$ Central Files (master copy)

$Y-12$ Central Files (route)

$Y-12$ Central Files (Y-12RC)

Paducah Gaseous Diffusion Plant

Levin, R. W.

Sandia-Albuquerque

Neilson, F. W.

Sandia-Livermore

Baker, A. F.

In addition, this report is distributed in accordance with the category UC-38, Engineering and Equipment, as given in the USAEC Standard Distribution Lists for Unclassified Scientific and Technical Reports, TID-4500. 